\title{
Sejarah Perkembangan Perlindungan Hak Asasi Manusia Pada Tersangka/Terdakwa Di Indonesia
}

\author{
RM Bagus Trisardono $\mathbf{R}$ \\ Fakultas Hukum Universitas Indonesia \\ Email: bagustsr@gmail.com
}

\begin{abstract}
Abstrak. Hak asasi manusia merupakan hak dasar yang melekat pada hakikat dan keberadaan manusia sebagai makhluk ciptaan Tuhan yang wajib dihormati, dijunjung tinggi dan dilindungi oleh siapapun. Terlepas dari statusnya, tersangka dan terdakwa merupakan warga negara yang memiliki jaminan atas hak asasi manusia nya, dan negara sebagai entitas utama wajib untuk memberikan perlindungan terhadapnya dari pelanggaran hak asasi manusia. Pengaturan perlindungan hak asasi manusia pada tersangka maupun terdakwa di Indonesia memiliki perjalanan panjang sejak masa penjajahan. Penelitian ini berusaha untuk menjelaskan bagaimana sejarah dan perkembangan perlindungan hak asasi manusia pada tersangka maupun terdakwa di Indonesia sejak sebelum lahirnya KUHAP hingga sekarang.
\end{abstract}

Kata Kunci: Sejarah, Perlindungan Hak Asasi Manusia, Hak Asasi Tersangka

Abstract. Human rights are basic rights inherent in the nature and existence of humans as God's creatures that must be respected, upheld and protected by anyone. Regardless of their status, suspects and defendants are citizens who have guarantees of their human rights, and the state as the main entity is obliged to provide protection against them from human rights violations. Arrangements for protecting human rights of suspects and defendants in Indonesia have had a long way to go since the colonial period. This study seeks to explain how the history and development of human rights protection for suspects and defendants in Indonesia since before the inception of the Criminal Procedure Code until now.

Key Words: History, Protection of Human Rights, Human Rights of Suspects

\section{PENDAHULUAN}

\section{Latar Belakang}

Pengertian mengenai tersangka dan terdakwa terdapat di dalam Pasal 1 butir 14 dan 15 Kitab Undang-Undang Hukum Acara Pidana (KUHAP): "Tersangka adalah seorang yang karena perbuatannya atau keadaannya, berdasarkan bukti permulaan patut diduga sebagai pelaku tindak pidana" dan "Terdakwa adalah seorang tersangka yang dituntut, diperiksa dan diadili di sidang pengadilan." Pengertian mengenai tersangka/terdakwa oleh kebanyakan orang sering disalahartikan. Mereka menganggap bahwa tersangka/terdakwa adalah orang yang bersalah (terpidana). Padahal yang berhak menentukan bersalah atau tidaknya seseorang adalah hakim melalui pengadilan dengan putusannya yang telah mempunyai kekuatan hukum tetap (in kracht van gewijsde). Hanya melalui hal tersebutlah seseorang baru dapat berstatus sebagai terpidana.

Dalam Wetboek van Strafvordering Belanda tidak ada pembedaan untuk istilah tersangka dan terdakwa (tidak lagi menggunakan dua istilah verdachte dan beklaagde, tetapi hanya ada satu istilah untuk kedua macam pengertian itu yaitu verdachte). Namun dibedakan pengertian verdachte sebelum penuntutan dan sesudah penuntutan. Pengertian verdachte sebelum penuntutan pararel dengan pengertian tersangka dalam KUHAP di Indonesia, sedangkan pengertian verdachte sesudah penuntutan pararel dengan pengertian terdakwa seperti pada Pasal 1 butir 15 KUHAP. Yang serupa dengan penggunaan istilah pada KUHAP ialah yang berlaku di Inggris, yaitu dengan membedakan pengertian 
the suspect (sebelum penuntutan) dan the accused (sesudah penuntutan).

Sistem peradilan pidana di Indonesia menganut asas praduga tidak bersalah (presumption of innocence). Secara eksplisit asas ini terdapat dalam butir ke 3 huruf c Penjelasan Umum Undang-Undang Nomor 8 Tahun 1981 Tentang Kitab Undang Undang Hukum Acara Pidana, sebagai berikut:

Setiap orang yang disangka, ditangkap, ditahan, dituntut dan atau dihadapkan di muka sidang pengadilan, wajib dianggap tidak bersalah sampai adanya putusan pengadilan yang menyatakan kesalahannya dan memperoleh kekuatan hukum tetap.

Oleh karenanya orang tersebut haruslah dilindungi dan dijaga setiap hak asasinya. Hal ini juga sejalan dengan penghargaan hak asasi manusia menurut UUD NRI 1945 yang mengatakan "Setiap orang berhak atas pengakuan, jaminan, perlindungan dan kepastian hukum yang adil serta perlakuan yang sama dihadapan hukum". Walaupun tidak tercantum secara jelas mengenai asas praduga tak bersalah tetapi dilihat dari rumusan pasal tersebut dapat ditelaah bahwa UUD NRI 1945 menjamin perlindungan dan adanya kepastian hukum yang adil serta perlakuan tidak diskriminasi di hadapan hukum, termasuk pula dianggap tidak bersalah sampai adanya putusan pengadilan yang berkekuatan hukum tetap.

Dalam konteks hak asasi manusia, negara menjadi subyek hukum utama, karena negara merupakan entitas utama yang bertanggung jawab melindungi, menegakkan, dan memajukan hak asasi manusia. Suatu negara hukum berhak untuk melakukan tindakan yang dibenarkan menurut hukum terhadap pelanggaran yang dilakukan oleh warga negaranya. Tindakan/upaya paksa itu dibenarkan menurut undang-undang demi kepentingan proses pemeriksaan tindak pidana, sehingga sudah sepantasnya tindakan itu wajib dilakukan secara bertanggungjawab sesuai ketentuan hukum dan undang-undang yang berlaku. Karena para penegak hukum dalam melaksanakan tugasnya tidak terlepas dari kemungkinan adanya perbuatan yang bertentangan dengan peraturan hukum yang berlaku sehingga menimbulkan pelanggaran hak asasi warga negara (tersangka atau terdakwa) dalam proses peradilan pidana, maka terhadap hal tersebut negara mengeluarkan peraturan-peraturan yang bertujuan sebagai bentuk perlindungan terhadap hak asasi manusia tersangka/terdakwa.

Saat ini di Indonesia terdapat beberapa peraturan perundang-undangan yang memberi perlindungan hak asasi manusia pada tersangka/terdakwa, antara lain yang terdapat pada Undang-Undang Nomor 8 Tahun 1981 Tentang Kitab Undang Undang Hukum Acara Pidana, Undang-Undang Nomor 5 Tahun 1998 Tentang Pengesahan Konvensi Menentang Penyiksaan dan Perlakuan atau Penghukuman Lain yang Kejam, Tidak Manusiawi, atau Merendahkan Martabat Manusia, UndangUndang Nomor 39 Tahun 1999 Tentang Hak Asasi Manusia, serta Undang-Undang Nomor 48 Tahun 2009 Tentang Kekuasaan Kehakiman.

\section{Rumusan Masalah}

Rumusan masalah yang akan diangkat dari penelitian ini adalah: Bagaimana sejarah dan perkembangan perlindungan hak asasi manusia tersangka/terdakwa di Indonesia?

\section{A.Sejarah dan Perkembangan Perlindungan Hak Asasi Manusia Tersangka/Terdakwa di Indonesia}

1. Sebelum Lahirnya Kitab UndangUndang Hukum Acara Pidana

Terdapat pemberlakuan dua hukum acara pidana yang berbeda secara sekaligus di wilayah Indonesia (Hindia Belanda) pada masa prakemerdekaan, yaitu Strafvordering (Rv) yang diberlakukan bagi golongan Eropa dan Inland Reglement (IR) bagi golongan pribumi yang kemudian diperbarui menjadi Herziene Indische Reglement (HIR) melalui Staatsblad No. 44 Tahun 1941. Strafvordering (Rv) memiliki pengaturan hukum acara pidana yang lebih baik dan lebih menghormati hak asasi tersangka/terdakwa. Sedangkan bagi golongan pribumi yaitu Inland Reglement maupun Herziene Indische Reglement (HIR), 
kedudukannya dianggap sebagai warganegara di negara jajahan.

Dalam Rv terdapat suatu bentuk upaya perlindungan terhadap hak-hak tersangka/terdakwa yaitu adanya hakim komisaris (rechter commissaris) yang diatur dalam title kedua tentang Van de regter commissarisen van de voorloopige informatien. Lembaga hakim komisaris berfungsi sebagai pengawas untuk mengawasi apakah tindakan upaya paksa, yang meliputi penangkapan, penggeledahan, penyitaan dan pemeriksaan surat-surat, dilakukan secara sah atau tidak. Hakim komisaris berperan sebagai pengawas pada tahap pemeriksaan pendahuluan dari serangkaian tahapan proses peradilan pidana. Lembaga ini juga memiliki kewenangan untuk melakukan tindakan eksekutif seperti memanggil orang, baik para saksi (Pasal 46) maupun tersangka (Pasal 47), mendatangi rumah para saksi maupun tersangka (Pasal 56), dan juga memeriksa serta mengadakan penahanan sementara terhadap tersangka (Pasal 62). Tindakan hakim komisaris yang termasuk tindakan eksekutif tersebut menunjukan bahwa kedudukannya bersikap aktif dan memiliki tanggung jawab pengawasan yang besar pada tahap pemeriksaan awal.

IR yang mengatur hukum acara pidana mulai berlaku pada tanggal 1 Mei 1848 untuk golongan bumiputera daerah Jawa dan Madura, sedangkan untuk wilayah di luar daerah Jawa dan Madura diberlakukan peraturan yang berbeda dalam bentuk Ordonansi-ordonanasi. Ordonansi-ordonansi tersebut kemudian dihimpun dan dijadikan satu dengan nama Recht-reglement buitengewesten (Reglement Daerah Seberang, Stb. 1927-227). Dalam perjalanannya, timbul kekhawatiran dari Gubernur Jenderal Rochussen terhadap diberlakukannya Reglement bagi golongan Pribumi, sehingga statusnya masih dalam percobaan. Usaha untuk melakukan beberapa perbaikan terhadap peraturan tersebut dilakukan oleh Mr. Wichers yang kemudian terjadi beberapa kali perubahan hingga munculnya Staatsblad 1941 No. 44 yang diumumkan dengan nama Herziene Inlands Regelement atau HIR.
Dalam IR tidak dapat ditemukan adanya badan penuntut umum tersendiri, sedangkan dalam HIR sudah ada. Meskipun demikian, IR tidak memberikan syarat-syarat tertentu terhadap tindakan penahanan tersangka secara sementara. Sedangkan didalam HIR diharuskan adanya syarat perintah tertulis. Kurungan sementara atas perintah asistenResiden menurut sistem lama (IR) diganti menjadi penangkapan selama 30 hari, dan dapat diperpanjang selama 30 hari atas perintah ketua Landraad. Penahanan sementara dan penangkapan hanya diperbolehkan untuk tindak pidana yang mempunyai ancaman pidana penjara 5 tahun atau lebih berat (Pasal 62 HIR). Dalam melakukan penggeledahan rumah pun diperlukan izin dari ketua Landraad, kecuali dalam hal tertangkap tangan dan keadaan mendesak (Pasal 77 dan 78 HIR). Serta wewenang untuk melakukan penyitaan barang-barang yang dapat dijadikan sebagai alat bukti diberikan kepada pegawai penuntut umum.

Pasca kemerdekaan Indonesia, aturanaturan yang berlaku di Indonesia pada zaman penjajahan, termasuk peraturan yang mengatur hukum acara pidana, masih diberlakukan sesuai pada asas konkordansi. Menurut Pasal II Aturan Peralihan UUD 1945, aturan-aturan tersebut dinyatakan masih berlaku selama belum ada undang-undang atau peraturan baru yang mencabutnya. Berdasarkan ketentuan tersebut, HIR dinyatakan masih berlaku dan dipergunakan sebagai hukum acara pidana di seluruh Indonesia. Hal ini diperkuat dengan adanya Pasal 6 UU No. 1 Drt/195, yang melakukan unifikasi dalam bidang hukum acara pidana, karena sebelumnya terjadi dualisme akibat perbedaan antara peradilan untuk golongan Pribumi dan golongan Eropa, yakni hukum acara pidana bagi Landraad dan hukum acara pidana bagi Raad van Justice.

Akibat diberlakukannya HIR maka hakim komisaris yang semula terdapat di RV tidak pergunakan lagi, sebab mekanisme tersebut tidak diatur didalam HIR dan kemudian hilang dalam sistem peradilan pidana Indonesia. Meskipun didalam HIR terdapat semacam pengawasan upaya paksa oleh hakim dalam bentuk perpanjangan waktu penahanan 
sementara yang harus dimintakan persetujuan hakim (Pasal $83 \mathrm{C}$ ayat (4) HIR), namun dalam praktiknya kontrol hakim ini kurang dirasakan manfaatnya, mengingat urusan perpanjangan penahanan oleh hakim itu bersifat tertutup dan semata-mata dianggap urusan birokrasi.

Dalam proses permohonan perpanjangan penahanan tersebut, semua berkas surat langsung ditandatangani oleh hakim ataupun petugas yang ditunjuk oleh hakim tanpa adanya pemeriksaan terlebih dahulu. Hal ini yang mengakibatkan banyaknya penahanan yang berlangsung hingga bertahun-tahun tanpa kejelasan dan tersangka yang bersangkutan tidak memiliki hak dan upaya hukum apapun yang tersedia baginya untuk melawan kesewenang-wenangan yang menimpa dirinya. Perlakuan dan cara pelaksanaan tindakan upaya paksa yang dilakukan penyidik pada waktu itu pun, semuanya lenyap ditelan kewenangan yang tidak terawasi dan tidak terkendali oleh koreksi lembaga mana pun. HIR tidak memberikan hak dan upaya hukum untuk tersangka memintakan perlindungan dan pengawasan. Penahanan tersangka selama bertahun-tahun dianggap lumrah dan tersangka tidak mempunyai kekuatan untuk mengadukan penderitaan itu kepada siapa pun, karena HIR tidak memiliki lembaga yang berwenang untuk menguji sah atau tidaknya tindakan upaya paksa yang dikenakan terhadap tersangka.

Keinginan Negara Indonesia untuk memperbaharui hukum acara pidananya dimulai pada tahun 1974 saat naskah RKUHP diajukan ke DPR berdasarkan surat Menteri Kehakiman No. 116/SM/K/11/74 perihal Konsep RUU tentang Hukum Acara Pidana dalam Lingkungan Peradilan Umum kepada Presiden RI tertanggal 19 November 1974. Pada rancangan tersebut diperkenalkan kembali fungsi pengawasan melalui lembaga hakim yang akan berperan dalam tahap pemeriksaan pendahuluan yang disebut "hakim komisaris".

Gagasan yang diajukan oleh Prof. Oemar Seno Adjie, S.H., yang pada saat itu menjabat sebagai Menteri Kehakiman, mirip dengan dengan konsep yang pernah ada dalam Reglement op de Strafvoerdering. Munculnya konsep hakim komisaris ini selain dilatarbelakangi banyaknya permasalahan dalam upaya paksa, juga berkehendak mewakili atau sebagai presentasi dari perlidungan hak asasi manusia, khususnya peran dan kedudukan korban dalam pra proses di pengadilan, yaitu tersangka. Upaya paksa yang dilakukan secara tidak sah merupakan pelanggaran serius terhadap hak asasi kemerdekaan dan kebebasan orang.

Dalam prosesnya, beberapa pihak kemudian menentang konsep hakim komisaris karena kewenangan yang dimilikinya dianggap terlalu luas. Pertikaian beberapa pihak yang setuju dengan yang menolak dimulai sejak konsep ini diajukan ke DPR. Penolakan terbesar datang dari kejaksaan yang berkeberatan akan adanya hakim komisaris. Kepolisian juga sangat keberatan dengan konsep hakim komisaris, Kepolisian dan Kejaksaan beranggapan bahwa kewenangan luas lembaga Hakim Komisaris ini akan menimbulkan benturan institusional, khususnya dengan lembaga (eksekutif) pelaksana dwang-middelen (upaya paksa) dalam proses peradilan itu sendiri, yaitu Penyidik dan Penuntut Umum.

\section{Setelah Lahirnya Kitab Undang-Undang Hukum Acara Pidana}

Lahirnya KUHAP dengan diterbitkannya Undang-Undang Nomor 8 Tahun 1981 merupakan suatu bentuk pembaharuan hukum yang signifikan. KUHAP telah mengangkat dan menempatkan seorang manusia dalam kedudukan yang bermartabat sebagai makhluk ciptaan Tuhan. KUHAP telah menempatkan seorang manusia dalam posisi dan kedudukan yang harus diperlakukan sesuai dengan nilainilai luhur kemanusiaan (his entity and dignity as a human being). Terkait dengan hal itu, sekalipun penegakan hukum merupakan hal mutlak dan menjadi suatu keharusan yang tidak bisa ditawar, tetapi HAM seorang tersangka juga tidak boleh diabaikan atau dilanggar.

Dalam KUHAP tidak dapat ditemukan konsep hakim komisaris yang diperbincangkan dalam naskah RKUHAP 1974, mengenai sistem pengawasan peradilan pidana diambil alih posisi nya oleh lembaga Praperadilan. Konsep lembaga Praperadilan merupakan gagasan dari Dr. A Buyung Nasution, S.H. 
yang mengambil prinsip-prinsip dalam Habeas Corpus dari Sistem Anglo Saxon yang memberikan hak sekaligus jaminan fundamental kepada seorang tersangka atau terdakwa untuk melakukan tuntutan ataupun gugatan terhadap pejabat (polisi atau jaksa) yang menahannya agar membuktikan bahwa penahanan itu benar-benar sah dan tidak melanggar hak asasi manusia, serta pengujian sah tidaknya dwang middelen melalui suatu forum terbuka.

Pada hakekatnya setiap upaya paksa yang dilakukan oleh penyidik atau penuntut umum itu merupakan tindakan yang dibenarkan dan disahkan, karena merupakan kewenangan yang diberikan oleh undang-undang demi kepentingan pemeriksaan tindak pidana. Setiap upaya paksa merupakan perampasan kemerdekaan dan kebebasan serta pembatasan terhadap hak-hak asasi manusia pada seorang tersangka. Apabila tindakan paksa itu dilakukan bertentangan dengan hukum dan undang-undang, maka hal itu merupakan pelanggaran terhadap hak-hak asasi tersangka, setiap tindakan pelanggaran hak asasi manusia yang dilakukan kepada tersangka adalah tindakan yang tidak sah, serta tidak dibenarkan oleh hukum dan undang-undang. Karenanya KUHAP merupakan ketentuan yang pada dasarnya dibuat untuk mengontrol perilaku aparat penegak hukum dalam melaksanakan tugasnya.

Berpijak dari pengalaman suram dimasa HIR, dimana pada saat itu tidak adanya sistem pengawasan terhadap upaya paksa, pembuat undang-undang menanggapi betapa pentingnya untuk menciptakan suatu lembaga yang diberi wewenang melakukan koreksi, penilaian, pengawasan terhadap setiap tindakan upaya paksa yang dikenakan oleh pejabat penyidik atau penuntut umum kepada tersangka, yang berlangsung selama pemeriksaan dalam tahap tingkat proses penyidikan dan penuntutan. Pelembagaan yang memberi wewenang pengawasan terhadap tindakan upaya paksa yang dilakukan pejabat dalam taraf proses pemeriksaan penyidikan atau penuntut umum inilah yang dilimpahkan KUHAP kepada Praperadilan. Konsep lembaga praperadilan menurut KUHAP terdapat dalam Pasal 1 angka 10, yaitu: Praperadilan adalah wewenang pengadilan negeri untuk memeriksa dan memutus menurut cara yang diatur dalam undang-undang ini, tentang:

a. Sah atau tidaknya suatu penangkapan dan atau penahanan atas permintaan tersangka atau keluarganya atau pihak lain atas kuasa tersangka;

b. Sah atau tidaknya penghentian penyidikan atau penghentian penuntutan atas permintaan demi tegaknya hukum dan keadilan;

c. Permintaan ganti kerugian atau rehabilitasi oleh tersangka atau keluarganya atau pihak lain atas kuasanya yang perkaranya tidak diajukan ke pengadilan.

Menjadi jelas bahwa nilai yang ingin dibawa dalam lembaga praperadilan adalah sebagai pembangunan hukum nasional yang membantu apa yang menjadi tujuan negara hukum demokratis, menjunjung tinggi dan menjamin harkat dan martabat manusia dan hak asasinya.

Tidak hanya lembaga Praperadilan yang menjadi suatu bentuk upaya perlindungan hak asasi tersangka/terdakwa. Menurut Mardjono Reksodiputro, terdapat 10 (sepuluh) asas dalam KUHAP, yang semuanya merupakan asas yang mengatur perlindungan terhadap harkat dan martabat tersangka/terdakwa, yang kemudian kesepuluh asas ini dapat dibedakan lagi menjadi tujuh asas umum, dan tiga asas khusus, yaitu:

Asas-asas umum:

1. Perlakuan yang sama di depan hukum tanpa adanya diskriminasi

Tidak saja terdapat pada Penjelasan KUHAP, melainkan juga tercantum dalam bagian Menimbang dari Undang-Undang Nomor 8 Tahun 1981. Perlakuan yang sama di depan hukum tidak hanya harus ditafsirkan dalam menghadapi tersangka/terdakwa yang berbeda dalam kedudukan atau kekayaan hartanya, tetapi harus lebih dari itu.

2. Praduga tidak bersalah

Terdapat pada butir 3 huruf c Penjelasan Umum KUHAP: Setiap orang yang disangka, ditangkap, ditahan, dituntut dan atau dihadapkan di muka sidang 
pengadilan, wajib dianggap tidak bersalah sampai adanya putusan pengadilan yang menyatakan kesalahannya dan memperoleh kekuatan hukum tetap

3. Hak untuk memperoleh kompensasi (ganti rugi) dan rehabilitasi

Penangkapan, penahanan, penuntutan yang dilakukan tanpa dasar hukum atau dilakukan karena kekeliruan, merupakan pelanggaran hak asasi manusia. Negara wajib untuk memberi ganti kerugian dan rehabilitasi bagi orang tersebut sebagai bentuk tanggung jawab. Dan kepada para aparat penegak hukum yang dengan sengaja atau karena kelalaiannya menyebabkan asas hukum itu dilanggar, maka dia akan dituntut, dipidana, dan/atau dikenakan hukuman administrasi.

4. Hak untuk mendapatkan bantuan hukum

Doktrin equality of arms didasarkan pada keadaan tersangka/terdakwa yang tidak seimbang (disadvantage) dalam menghadapi negara. Melalui aparat kepolisian dan kejaksaan, negara selalu mempunyai kesempatan yang lebih besar dibanding dengan tersangka/terdakwa.

5. Hak kehadiran terdakwa di muka pengadilan

Asas ini bertujuan terciptanya keseimbangan dalam kesempatan untuk berargumen, baik bagi pihak aparat penegak hukum maupun bagi tersangka/terdakwa. Dengan berpedoman pada proses hukum yang adil, bagaimanapun kuatnya buktibukti yang dimiliki oleh polisi atau jaksa penuntut umum, pendapat tersangka/terdakwa juga masih harus didengar dan dipertimbangkan.

6. Peradilan yang bebas dan dilakukan dengan cepat serta sederhana

Peradilan yang bebas tidak akan mengizinkan timbulnya anggapan seseorang telah dinyatakan bersalah sebelum ada pembuktian yang kuat terhadap perbuatannya, serta tidak akan mengizinkan adanya show trials di mana terdakwa tidak diberikan kesempatan yang layak untuk membela diri dan di mana orang sudah dapat menduga bahwa putusan hakim akan mempermasalahkan terdakwa tanpa menghiraukan pembuktian ataupun pembelaan. Asas ini juga dimaksudkan untuk mengurangi sampai seminimal mungkin waktu penderitaan tersangka maupun terdakwa, karena keinginan untuk keputusan yang secepatnya.

7. Peradilan yang terbuka untuk umum

Asas ini memiliki tujuan agar masyarakat dapat ikut mengawasi terjaminya perlindungan hak-hak terdakwa dalam pengadilan.

Asas-asas khusus:

1. Pelanggaran atas hak-hak individu berupa penangkapan, penahanan, penggeledahan dan penyitaan harus didasarkan pada undang-undang dan dilakukan dengan surat perintah

Jaminan hak kemerdekaan seseorang hanya boleh dilanggar berdasarkan syaratsyarat yang telah ditentukan oleh undangundang dan dilakukan oleh pejabat negara yang diberi wewenang oleh undangundang pula. Pelanggaran yang berupa penangkapan, penahanan, penggeledahan dan penyitaan itu, hanya boleh dilakukan sesuai dengan ketentuan KUHAP. Apabila asas ini dilanggar, maka mekanisme praperadilan dapat ditempuh oleh pihak yang telah dirugikan. Menurut Andi Hamzah, praperadilan merupakan tempat mengadukan pelanggaran HAM. Niat dibentuknya praperadilan ialah sebagai "terjemahan" dari habeas corpus yang merupakan substansi perlindungan HAM.

2. Hak seorang tersangka untuk diberitahukan tentang persangkaan dan pendakwaan terhadapnya

Asas ini merupakan bagian dari pemahaman yang benar tentang proses hukum yang adil (due process of law), di mana tersangka/terdakwa harus diberikan jaminan-jaminan untuk dapat membela diri sepenuh-penuhnya, karena seorang tersangka tidak dapat melakukan pembelaan dirinya dalam proses interogasi oleh penyidik apabila dia tidak diberitahu dengan jelas alasan penangkapannya. Asas ini juga menjelaskan mengapa penasehat hukum sejak saat penangkapan berhak untuk melihat berkas perkara yang disusun oleh 
penyidik sebagai dasar pengajuan perkara kepada jaksa penuntut umum.

3. Kewajiban pengadilan untuk mengendalikan pelaksanaan putusanputusannya

Dalam hal pidana perampasan kemerdekaan (pidana penjara), ketepatan putusan pengadilan tersebut masih perlu diuji. Untuk itulah dalam KUHAP terdapat lembaga Hakim Pengawas dan Pengamat (Hakim Wasmat) yang bertujuan menjaga agar perlakuan terhadap terpidana tidak menyalahi asas pemidanaan.

Perlindungan hak asasi manusia yang tercermin dalam KUHAP merupakan pengaruh transformasi dari sistem Anglo Saxon. Inggris memiliki "judges's rules" dan Amerika berpegang teguh pada "exclusionary rules", yang keduanya merupakan aturan yang berlaku umum dan berisikan kewajiban aparat penegak hukum dalam melaksanakan tugasnya, antara lain larangan melakukan pelanggaran terhadap tersangka, termasuk masalah hak-hak tersangka berkenaan dengan penangkapan dan penahanan.

Perkembangan perlindungan hak asasi manusia tersangka/terdakwa pada masa setelah lahirnya KUHAP juga dipengaruhi oleh beberapa peraturan perundang-undangan yang lahir setelah diberlakukannya KUHAP, yaitu:

1) Undang-Undang Nomor 5 Tahun 1998

Tentang Pengesahan Konvensi Menentang

Penyiksaan dan Perlakuan atau

Penghukuman Lain yang Kejam, Tidak

Manusiawi, atau Merendahkan Martabat

Manusia

Pemerintah Republik Indonesia menandatangani Konvensi Menentang Penyiksaan dan Perlakuan atau Penghukuman Lain yang Kejam, Tidak Manusiawi, atau Merendahkan Martabat Manusia pada tanggal 23 Oktober 1985, yang kemudian diratifikasi pada tahun 1998 melalui undang-undang ini. Konvensi ini merupakan tindak lanjut dari Declaration Against Torture and Other Cruel, Inhuman or Degrading Treatment or Punishment yang disahkan oleh PBB pada tanggal 9 Desember 1975.

Pasal-pasal penting dalam Undangundang ini yang menjadi landasan hukum bagi perlindungan hak asasi tersangka/terdakwa adalah Pasal 2, Pasal 10, Pasal 11, Pasal 12, Pasal 13, dan Pasal 14. Pada intinya melalui pasal-pasal ini terhadap tersangka/terdakwa dalam menjalani suatu proses hukum pidana harus mendapatkan perlakuan yang sama di hadapan hukum, mendapatkan jaminan perlindungan hukum agar dia tidak disiksa, diperlakukan yang kejam atau tidak manusiawi, serta diadili melalui proses peradilan yang bebas dan tidak memihak, sesuai dengan hukum acara yang menjamin pemeriksaan yang objektif oleh hakim yang jujur dan adil untuk memperoleh putusan yang adil dan benar.

2) Undang-Undang Nomor 39 Tahun 1999 Tentang Hak Asasi Manusia

Terbentuknya Undang-undang ini berasal dari suatu kenyataan dan tantangan reformasi hukum di Indonesia. Tuntutan reformasi hukum menggariskan kepada negara untuk menjamin hak-hak dasar setiap warga negara dalam memperoleh perlindungan dan keadilan hukum. UU No. 39 Tahun 1999 lahir dari sikap positif Pemerintah RI atas resolusi Komisi Tinggi HAM PBB yang menyatakan bahwa setiap negara anggota PBB berkewajiban melindungi hak-hak dasar warga negaranya tanpa membeda-bedakan suku, bangsa, agama, bahasa, dan status sosial lainnya.

Undang-Undang ini memuat ketentuan mengenai hak asasi manusia secara universal, namun dalam konteks hak asasi tersangka, Undang-undang ini memiliki beberapa pasal yang menjadi dasar-dasar dalam perlindungan hak asasi tersangka, yang antara lain adalah:

a. Hak perlindungan pribadi, keluarga, kehormatan, martabat dan hak miliknya.

b. Hak mendapat ketentuan yang paling menguntungkan apabila terdapat perubahan pada peraturan perundangundangan.

c. Hak terbebas dari penyiksaan, penghukuman atau perlakuan yang kejam, tidak manusiawi, merendahkan derajat dan martabat kemanusiaannya.

d. Hak untuk tidak diperlakukan secara sewenang-wenang dalam proses penangkapan, penahanan maupun dalam hal diasingkan ataupun dikucilkan 
e. Hak untuk tidak menerima perlakuan yang dapat menimbulkan rasa sakit atau penderitaan yang hebat secara jasmani maupun rohani dengan kepentingan untuk memperoleh pengakuan atau keterangan.

f. Hak untuk memperoleh keadilan tanpa diperlakukan secara diskriminasi dari pihak manapun.

g. Hak untuk dianggap tidak bersalah sampai adanya putusan yang berkekuatan hukum tetap.

h. Hak untuk tidak dituntut kecuali berdasarkan peraturan yang ada sebelum tindak pidana itu dilakukan.

i. Hak untuk mendapatkan bantuan hukum sejak awal pemeriksaan sampai pada proses adanya putusan di pengadilan.

Undang-undang ini juga memuat mengenai Komisi Nasional Hak Asasi Manusia (Komnas HAM) yang merupakan lembaga independen yang bertujuan untuk meningkatkan perlindungan dan penegakan hak asasi manusia. Komnas HAM dirasa akan sangat memberi dampak positif terhadap perlindungan hak asasi manusia khususnya tersangka/terdakwa karena lembaga ini bersifat aktif dalam melakukan penyidikan dan pemeriksaan terhadap peristiwa yang diduga sebagai pelanggaran hak asasi manusia.

3) Undang-Undang Nomor 48 Tahun 2009 Tentang Kekuasaan Kehakiman

Perlindungan terhadap hak asasi tersangka/terdakwa juga dapat ditemukan dalam Undang-undang ini, yang secara eksplisit memuat ketentuan-ketentuan sebagai berikut:

a. Penegasan adanya asas praduga tak bersalah (presumption of innounce), dimana dijelaskan bahwa setiap orang yang disangka, ditahan, dituntut, dan/atau dihadapkan di depan pengadilan wajib dianggap tidak bersalah sebelum ada putusan pengadilan yang menyatakan kesalahannya dan telah memperoleh kekuatan hukum tetap. Karenanya setiap penyidik dan penuntut umum tidak boleh memberikan keterangan kepada siapapun terhadap suatu tindak pidana yang disangkakan kepada tersangka, bahwa tersangka merupakan yang bersalah (terpidana) dalam tindak pidana tersebut sampai adanya putusan yang berkekuatan hukum tetap.

b. Asas persamaan dihadapan hukum, dimana hakim dalam mengadili tidak boleh membeda-bedakan orang dalam hal apapun, serta berusaha mengatasi segala hambatan dan rintangan untuk dapat tercapainya peradilan yang sederhana, cepat, dan biaya ringan. Merupakan tuntutan logis dari setiap tersangka/terdakwa untuk menjalani proses peradilan pidana yang cepat dan sederhana. Seorang tersangka atau terdakwa yang berada dalam tahanan berhak untuk menuntut diadili dalam jangka waktu yang wajar.

c. Asas sidang terbuka untuk umum, untuk menghindari keadaan dimana masyarakat tidak dapat mengawasi secara seksama apakah pengadilan telah memperhatikan hak-hak terdakwa.

d. Hak untuk mendapat ganti kerugian dan rehabilitasi apabila terjadi kekeliruan dalam penangkapan, penahanan, penuntutan, dan diadili tanpa alasan berdasarkan undang-undang.

e. Hak untuk memperoleh bantuan hukum berupa menghubungi dan meminta dampingan dari advokat atau penasehat hukum sejak saat dilakukannya penangkapan dan atau penahanan.

\section{Kesimpulan}

Hak asasi manusia merupakan seperangkat hak yang melekat pada hakikat dan keberadaan manusia sebagai makhluk Tuhan Yang Maha Esa dan merupakan anugrah-Nya yang wajib dihormati, dijunjung tinggi dan dilindungi oleh negara, hukum, pemerintah dan setiap orang demi kehormatan serta perlindungan harkat dan martabat manusia. Hal demikian termasuk juga terhadap para tersangka/terdakwa. Terlepas dari perbuatan-perbuatannya, mereka juga tetap makhluk ciptaan Tuhan yang harus dihormati hak asasi manusia nya. Tindakan/upaya paksa kepada tersangka/terdakwa memang dibenarkan menurut undang-undang demi kepentingan proses pemeriksaan tindak pidana. Namun apabila tindakan paksa itu dilakukan bertentangan dengan hukum dan 
undang-undang, maka hal itu merupakan perkosaan terhadap hak-hak asasi tersangka/terdakwa.

Sebelum berlakunya KUHAP tahun 1981, para tersangka/terdakwa tidak mendapatkan perlindungan hak-haknya dengan baik dikarenakan hukum yang berlaku saat itu adalah hasil konkordansi dari zaman belanda, yaitu Herziene Indische Reglement (HIR). Di dalam HIR tidak dapat ditemukan sistem pengawasan dan pengujian serta penilaian terhadap sah atau tidaknya suatu upaya paksa yang dilakukan aparat penegak hukum. Sehingga segala bentuk tindakan paksa pada saat itu akan lenyap ditelan kewenangan yang tidak terawasi.

Berpijak dari pengalaman suram di HIR, pemerintah menanggapi betapa pentingnya menciptakan peraturan perundang-undangan yang dapat mengatasi permasalahan kesewenang-wenangan tindakan upaya paksa. Sehingga pada tahun 1981 lahirlah Kitab Undang-Undang Hukum Acara Pidana yang berisikan asas-asas perlindungan hak asasi tersangka, serta terbentuknya suatu lembaga yang memiliki wewenang untuk melakukan koreksi dan penilaian terhadap upaya paksa, yaitu lembaga Praperadilan. Gagasan hakim komisaris digusurkan karena pada saat itu pembuat undang-undang beranggapan lembaga praperadilan lebih tepat.

Pemerintah pada tahun 1998 meratifikasi Konvensi Menentang Penyiksaan dan Perlakuan atau Penghukuman Lain yang Kejam, Tidak Manusiawi, atau Merendahkan Martabat Manusia sebagai bentuk kepedulian terhadap hak asasi manusia khususnya hak tersangka/terdakwa.

Untuk lebih menjamin perlindungan hak asasi manusia khususnya hak tersangka, pemerintah mengeluarkan UU No. 39 Tahun 1999 tentang HAM yang dapat ditemukan beberapa hak-hak serta asas perlindungan tersangka/terdakwa. Dalam Undang-Undang ini juga memuat Komnas HAM yang bertujuan untuk meningkatkan perlindungan dan penegakan hak asasi manusia. Dalam UU No. 48 Tahun 2009 tentang Kekuasaan Kehakiman juga dapat ditemukan asas-asas yang menperhatikan hak-hak tersangka/terdakwa.
Dapat dilihat dari sejarah dan perkembangan diatas bahwa pemerintah sangat memperhatikan hak-hak asasi tersangka, karena dalam setiap peraturan yang dibuatnya mengandung pengaturanpengaturan mengenai perlindungan terhadap hak asasi tersangka/terdakwa.

\section{Tanggapan}

Hak asasi manusia khususnya hak asasi tersangka sudah sepatutnya untuk dihargai dan dilindungi dari segala tindakan-tindakan sewenang-wenang. Asas praduga tidak bersalah harus selalu di utamakan dalam memproses tersangka/terdakwa baik sejak penangkapan hingga sebelum dikeluarkannya putusan hukum yang tetap.

Pemerintah sudah seharusnya lebih memperhatikan hak asasi manusia pada tersangka dengan menekankan peraturan yang ada kepada para pihak terkait agar lebih mengetahui dan dapat mengontrol tindakantindakannya agar tidak terjadi pelanggaran hak asasi tersangka. Serta dengan mengevaluasi peraturan perundang-undangan yang ada dan diselaraskan dengan situasi saat ini guna dapat lebih meningkatkan jaminan perlindungan terhadap hak asasi manusia pada tersangka/terdakwa.

\section{DAFTAR PUSTAKA \\ Buku}

Andi Hamzah, Hukum Acara Pidana Indonesia, (Jakarta: Sinar Grafika, 2004). Darwan Prinst, Hukum Acara Pidana dalam Praktik, (Jakarta: Djambatan, 2014).

Didi Sunardi dan Endra Wijaya, Perlindungan Hak Asasi Manusia Tersangka/Terdakwa, (Jakarta: PKIH FHUP, 2011).

Frans Ceunfin, ed., Hak-Hak Asasi Manusia: Pendasaran dalam Filsafat Hukum dan Filsafat Politik, (Maumere: Ledalero, 2004).

Luhut MP. Pangaribuan, Hukum Acara Pidana: Surat-Surat Resmi di Pengadilan oleh Advokat, (Jakarta: Djambatan, 2005).

M. Yahya Harahap, Pembahasan Permasalahan dan Penerapan KUHAP, Penyidikan dan Penuntutan, (Jakarta: Sinar Grafika, 2006).

Mardjono Reksodiputro, Hak Asasi Manusia dalam Sistem Peradilan Pidana, 
Kumpulan Karangan Buku ke Tiga, (Jakarta: Pusat Pelayanan Keadilan dan Pengabdian Hukum, Lembaga Kriminologi Universitas Indonesia, 1999). Prija Djatmika, Politik Hukum Pidana untuk Perlindungan Tersangka dari Tindakan Penyiksaan, (Jakarta: Prestasi Pustaka, 2006).

Tim Studi ELSAM, Ke Arah Ratifikasi Konvensi Anti Penyiksaan: Kajian KasusKasus Penyiksaan Belum Terselesaikan, (Jakarta: ELSAM, 1995),

\section{Jurnal}

I Nyoman Arnita, "Perlindungan Hak-Hak Tersangka dalam Penahanan ditinjau dari Aspek Hak Asasi Manusia", Jurnal Hukum, Vol.XXI No 3, 2013.

Indriyanto Seno Adji, Hakim Komisaris: Solusi ke arah Prinsip Keadilan, Hukum dan Pembangunan, Nomor 3 Tahun XXXII.

Institute for Criminal Justice Reform (ICJR), "Praperadilan di Indonesia: Teori, Sejarah, dan Praktiknya”, Publikasi Ilmiah, 2014.

Peraturan Perundang-Undangan

Undang-Undang Dasar Negara Republik Indonesia Tahun 1945

Undang-Undang Nomor 8 Tahun 1981 Tentang Kitab Undang Undang Hukum Acara Pidana

Undang-Undang Nomor 5 Tahun 1998 Tentang Pengesahan Konvensi Menentang Penyiksaan dan Perlakuan atau Penghukuman Lain yang Kejam, Tidak Manusiawi, atau Merendahkan Martabat Manusia

Undang-Undang Nomor 39 Tahun 1999 Tentang Hak Asasi Manusia

Undang-Undang Nomor 48 Tahun 2009 Tentang Kekuasaan Kehakiman 